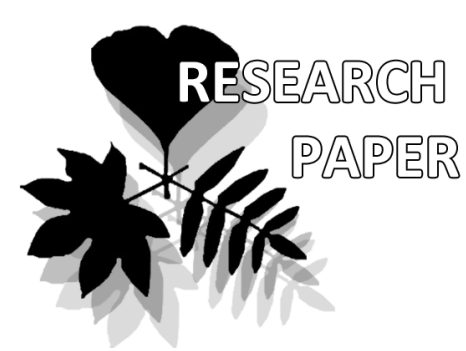

\title{
Approach to Identification of Fossil Angiosperm Leaves: Applicability and Significance of Krassilov's Morphological System
}

\author{
Natalia P. Maslova ${ }^{1 *}$ and Alexei B. Herman ${ }^{2}$
}

Natalia P. Maslova ${ }^{1 *}$

e-mail: paleobotany_ns@yahoo.com

Alexei B. Herman ${ }^{2}$

e-mail: alexeiherman@gmail.com

${ }^{1}$ A.A. Borissyak Paleontological Institute, Russian Academy of Sciences, Moscow, Russia

${ }^{2}$ Geological Institute, Russian Academy of Sciences, Moscow, Russia

* corresponding author

Manuscript received: 31.07.2015

Review completed: 14.08 .2015

Accepted for publication: 23.09.2015

Published online: 25.09.2015

\begin{abstract}
A B S T R A C T
Recent studies of the Cretaceous platanoid plants have shown that a morphological classification of leaves proposed by Krassilov seems to be the most effective key for the identification of fossil (Cretaceous and Tertiary) dispersed leaves of angiosperms. This classification is independent from the system of modern plants.
\end{abstract}

K e y w o r d s : fossil angiosperm leaves, morphological system, Ettingshausenia

\section{P E 3 Ю M E}

Маслова Н.П., Герман А.Б. Подход к определению Аистьев ископаемых покрытосеменных: применимость и значимость морфологической системы Красимова. Полученные в последнее время результаты изучения меловых платаноидных Аистьев позволяют считать, что наиболее приемлемой Аля определения ископаемых (меловых и третичных) Аисперс-

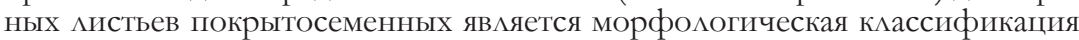
мистьев, предложенная Красиловым. Эта классификация является независимой от системы современных растений.

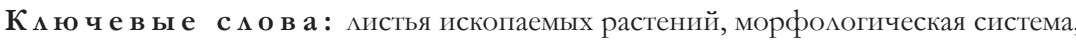
Ettingshausenia
In 1979, Valentin Krassilov published a book entitled "Cretaceous Flora of Sakhalin" with a brief description of the new morphological system of fossil angiosperm dispersed leaves. The need of such a system for palaeobotany has been proved by him later (Krassilov 1989) and confirmed by Meyen (1987) and other authors (Maslova et al. 2005b, Herman \& Kvaček 2010). However, it has never been elaborated in details that made it difficult for widespread use. The importance of this system has increased in recent years as new extensive data on the dispersed fossil angiosperm leaves and related reproductive structures have been obtained.

The idea of a new morphological classification first emerged during the taxonomic study of the early angiosperms that Krassilov conducted as part of a broader analysis of angiosperms evolution. The attribution of Cretaceous angiosperms (mostly leaf remains) to extant genera or higher taxa long prevailed in palaeobotany, and this approach is still in use. In the 18th and 19th centuries, paleobotanists identified the flowering plants of fossil floras by related modern genera mostly on the basis of the rough morphological similarities of their leaves. The selection of an appropriate living plant by leaf macromorphology is not difficult because of the huge variety of leaves in the modern angiosperms. However, angiosperms that are fairly distant from a systematic point of view may have very similar leaves. Therefore, the determination of fossil leaves within the scope of the system of the extant angiosperms is very subjective and may lead to misinterpretation and to significant loss of information. Moreover, this approach has resulted in the mistaken assumptions that in the Creta- ceous most angiosperms were already represented by extant genera and families and, therefore, had long evolved and that the time of this group first appearance was early Mesozoic or even Paleozoic. That would mean that the existing palaeobotanical data were not that important for revealing of phylogeny of those plants.

The problem of the validity of the assignment of Cretaceous fossil leaves to extant genera or higher taxa was raised back to the end of the 19th century. By the middle of the 20th century, it has become obvious that the early definitions of the angiosperms, based exclusively on their modern analogues, need corrections. However, so called revision was limited by putting the modern generic names in quotes; when leaf remains that resembled leaves of extant plants were only loosely determined (due to observed differences, unusual combination of characters, or insufficient preservation of fossil material), the endings -phyllum or -ites were added to the most relevant modern generic name. A genus of this type was believed to correspond to several extant genera, or an extant family, or even an order. Although the endings -phyllum and -ites imply that the fossil plants in question have certain differences from their extant analogues and, therefore, the application of such names is unequivocally better than the assignment of Cretaceous fossils directly to extant taxa, the problem has persisted: such genera are frequently regarded as closely related to the relevant extant genera and are usually placed together with them in modern families (and higher taxa) in the system of modern angiosperms. However, numerous examples show that the assignment of Cretaceous angiosperm leaves to 
modern genera and families is erroneous or, at least, needs more support.

The positioning of a fossil plant within the natural plant system is considered to be the major purpose of the systematic palaeobotany. Therefore, it is important to define a set of criteria for doing this as well as to reveal a set of the diagnostic features. Quite often this is being done customarily, without a proper accuracy and a comprehensive analysis. In this case, only the morphological features of angiosperm leaves are used, since their preservation is usually not good enough for ther epidermal study.

Such an approach provokes an establishment of new species or even genera based on the minute variations of morphological features. This leads to an overestimation of the taxonomic variability and the general interpretation of a fossil flora becomes simply incorrect. In order to avoid this, Krassilov has developed his morphological classification of dispersed fossil angiosperm leaves (mostly Cretaceous, but also the Tertiary ones).

The essence of this classification is in using exclusively the observed features of leaf morphology with fossil leaves of a certain morphological type being attributed to a particular genus. Krassilov (1979, p. 43) noticed, that "only an inductive system with clear diagnoses of the taxa (each taxon includes leaves of a definite morphological type rather than those resembling leaves of a particular extant genus) and consistent application of the principle of priority to names can provide a common language and reduce the loss of information". This approach allows a paleobotanist to trace the appearance of a particular leaf morphotype, its geological history, and proportions of particular leaf morphotypes within certain time intervals and certain fossil floras. Such a classification is independent from the natural system of modern plants. This means that the taxa of the dispersal leaves morphological classification do not match those established for the entire plants. As Meyen (1987, p. 252) noticed, " ... the main goal of this system is to choose leaves of plants that are worth comparing with the fossils being studied".

The idea of using the names based on this classification for dispersed fossil angiosperm leaves was discussed in detail by the authors earlier (Maslova et al. 2005b). Since that time, additional data supporting this approach has emerged. At the same time, this approach has been critisized by a number of researches. This has encouraged us to look at this problem again.

The justification for the use of Krassilov's morphological classification is well illustrated by an example of fossil leaves possessing lobes (or poorly developed lobes) and actinodromous venation, similar in their morphology with leaves of modern plane trees (Platanus). At the moment, the evolutionary history of the extant family Platanaceae, based on both leaf and reproductive structure remains, is amongst the most well elaborated (Krassilov 1973, Manchester 1986, Friis et al. 1988, Maslova 2003). It has been shown that the polymorphic group of genera more or less similar to the modern Platanus and belonging to both extant and extinct families, has existed since Early Cretaceous (Maslova 2010). Reproductive structures, indistinguishable superficially (in gross morphology) from those of the modern plane tree, are attributable in their microstructures to different genera and even families whilst the associated leaves are very similar to each other and represent a single morphological type.

By analysing the data on the dispersed fossil Platanuslike leaves, it is possible to distinguish conditionally three different groups of them. Those without any information on the epidermal structures due to the insufficient preservation form the first group (Group \#1) (Pl. 1, fig. 2, 3). Those leaves are typical and even predominant in, for instance, many Cretaceous and Cenosoic floras of the Northeastern Russia, Kazakhstan and Europe.

The second group (Group \#2) includes Platanus-like leaves possessing epidermis typical for the modern planetree (Pl. 1, fig. 4; Pl. 2, fig. 1). In general, the epidermal structure of all moderm Platanus species is uniform. The following set of epidermal features is diagnostic for this genus: anomocytic or laterocytic stomata, trichome bases associated with multiple (more than two) epidermal cells, cuticular folds spreading radially from the trichome bases and/or stomata (Pl. 2, fig. 3, 4). These features have been developed in platanoid leaves as early as in Albian (Upchurch 1984) and remained unaltered since then. A number of features (dimensions of cells and stomatal complexes, the pattern of anticlinal walls of the ordinary epidermal cells, the number of trichomes and stomata per unit area) vary with plant growth conditions and even with the leaf positioning within a crown of a single plant. These features, taken on their own, cannot be considered as diagnostic.

The third group (Group \#3) includes Platanus-like leaves possessing epidermis not typical of Platanaceae. The most vivid example of this could be fossil leaves from the Cenomanian-Turonian of Sarbai locality in West Kazakhstan (Maslova \& Shilin 2011; see Pl. 2, fig. 2). Being characterised by platanoid leaf morphology, they nevertheless possess a unique epidermal structure not typical at all for Platanaceae (Pl. 2, fig. 5).

Thus, the leaves from three groups described above are characterised by identical leaf morphology but, at the same time, by different degree of knowledge about their epidermal structure. Namely, their epidermis could be either typical or atypical of Platanus, or any information on it could be missing. A systematic palaeobotanist is confronted with a question: how to define a taxonomic assignment of such fossils?

Probably, it would be correct to attribute the fossil leaves from Group \#2 to the modern family Platanaceae due to similarity of both leaf morphology and epidermal structure to those of the modern Platanus. However, it has to be taken into account that in this case we deal with a single plant organ, namely a leaf, whilst the structure of the other organs remains unknown and, consequently, it is not possible to judge whether or not they are completely similar to those of the modern plane-tree. In fact an assignment of a fossil leaf to a modern genus or family implies (as a rule, unjustifiably) that all other, usually unknown, organs of the fossil plant are the same as in living representatives of this taxon. However, as a rule we lack any proof of such implication. According to the evocative metaphor of 
Meyen, in this case we act like someone who found a nut on the railway and claimed to have found a steam locomotive. Moreover, an association of Albian-Cenomanian Platanuslike leaves possessing a typical platanoid epidermis with reproductive structures which on the microstructural level are significantly different from those of Platanus is known (Maslova et al. 2011).

As to the Group \#1 leaves, it should be emphasised that researches used to distinguish a large number of Platanus species from one and the same locality based only on minute variations in leaf morphology (such as base shape, marginal tooth size and density and secondary vein density). Morphological variability characteristic to the modern Platanus are practically not accounted for in these definitions. Mainly this is a typical problem of publications from the mid 20th century (Yarmolenko 1935, Vachrameev 1952). Reevaluations of such fossils has been already started (Kvaček \& Váchová 2006, Moiseeva 2008, 2009). A number of researchers accept the idea of the morpholodical classification of dispersed leaves and use the generic name Ettingshausenia as suggested by Maslova et al. (2005b) for new finds of fossil Platanus-like leaves (Narita et al. 2008, Shilin 2008). However, the majority of platanoid taxa still remain to be revised. Anyway, to ascribe a leaf fossil lacking any information on its epidermal features and the associated reproducrive structures to a modern family seems to be invalid or, at least, very risky.

For the Cretaceous Platanus-like leaves a combination of encyclocytic, incompletely amphicyclocytic, laterocytic, or paracytic stomata as well as the presence of trichomes developing on one to seven epidermal cells have been demonstrated (Maslova \& Shilin 2011). It is worth noting that encyclocytic and incompletely amphicyclocytic stomata are unknown in modern Platanus species. Therefore it seems to be incorrect to assign these fossil leaves of the Group \#3 to the modern family Platanaceae ignoring the uniqueness of their epidermis.

Also important is that there are numerous examples when the Platanus-like leaves are associated with various infructescences and staminate inflorescences different from those of Platanus (Krassilov 1976, Krassilov \& Shilin 1995, Maslova \& Herman 2004, 2006, Maslova et al. 2005a, Maslova et al. 2011). For this reason it is possible to analyse these associations due to their repeatability (Maslova 2010). Strongly different fossil genera established on the basis of their reproductive organ structures, more or less similar to the platanoids, imply that a polymorphic plant group, which has given rise to the modern genus, existed in the geologic past. It is quite likely that these plants possessed Platanuslike foliage. These data are particularly important for the discussion on the dispersed fossil Platanus-like leaves nomenclature since they clearly demonstrate that plants with Platanus-like leaves and non-Platanus-like reproductive organs did exist in fossil floras. Obviously these leaves are impossible to ascribe to the modern family Platanaceae.

Earlier we proposed that dispersed fossil Platanuslike leaves should be assigned to the genus Ettingshausenia Stiehler of the morphological system independent of the natural modern plant system (Maslova et al. 2005b). This approach allows summarising the information on the stratigraphic and geographic distribution of Platanus-like leaves and avoiding any taxonomic errors within the natural plant system. Obviously any discussions on the similarities/dissimilarities of these leaves (different species of the genus Ettingshausenia) with the plants from different families of the natural plant system should be highly encouraged.

This approach has been critisised by a number of palaeobotanists. So, according to Tschan et al. (2008), the genus Ettingshausenia as Maslova et al. (2005b) define it, «... would become a 'garbage can' genus for possibly unrelated taxa». However, here the emphasis should be made on the basic principles of Krassilov's morphological classification. Firstly, this system should be based on observed features of leaf morphology rather than on weak and often erroneous hypotheses about the morphology of the whole plant. Secondly, such a classification does not depend on the system of modern plants: there is no unambiguous correspondence between taxa of the morphological system and taxa that were established to describe whole plants. To put it differently, a genus of the morphological system may occur in more than one genus or even family of whole plants and, vice versa, the latter may be supplied by leaves belonging to more than one genus of the morphological system (Herman \& Kvaček 2010). Obviously, the above reminiscence ('garbage can') by Tschan et al. (2008) is due to their misunderstanding of these principles.

On the contrary, placing numerous new genera based on fossil leaves with different combinations of morphological and/or some epidermal features, both quantitative and dimentional, in a modern family distort a real diversity of the latter in the geologic past and therefore makes it a 'rubbish bin' family. Moreover, a number of fossils (leaves lacking epidermal characteristics) are left beyond the analysis.

A different approach has been chosen by Golovneva (2011, Golovneva \& Nosova 2012) who combined all such Platanus-like fossil leaves from the vast area of Western Europe (Czech Republic and Germany), West Siberia and Kazakhstan into a single species Ettingshausenia cuneifolia (Bronn) Stiehler. The genus Ettingshausenia is considered by her to be monotypic (with one species only) within the family Platanaceae of the natural system. Golovneva (2011) also published an emended diagnosis of Ettingshausenia combining both morphological and epidermal characteristics. In our opinion, this taxonomic decision cannot be justified.

By including Ettingshausenia sarbaensis $\mathrm{N}$. Maslova et Shilin (Maslova \& Shilin 2011), which differs from other species of this genus in having encyclocytic stomata alongside with other stomatal types, in the synonimy of Ettingshausenia cuneifolia, Golovneva (2011, p. 148) has introduced a new epidermal characteristic, namely the presence of "encyclocytic stomata", in the Ettingshausenia generic diagnosis. In the description of Ettingshausenia cuneifolia she points out that this stomatal type is the most common (Golovneva 2011, p. 154). Considering that encyclocytic stomata are unknown in modern plane tree (and, consequently, in the modern family Platanaceae), this conclusion is at least surprising. We believe that it is totally incorrect to widen a set of diagnostic characteristics of a modern family by including in it, without an ap- 

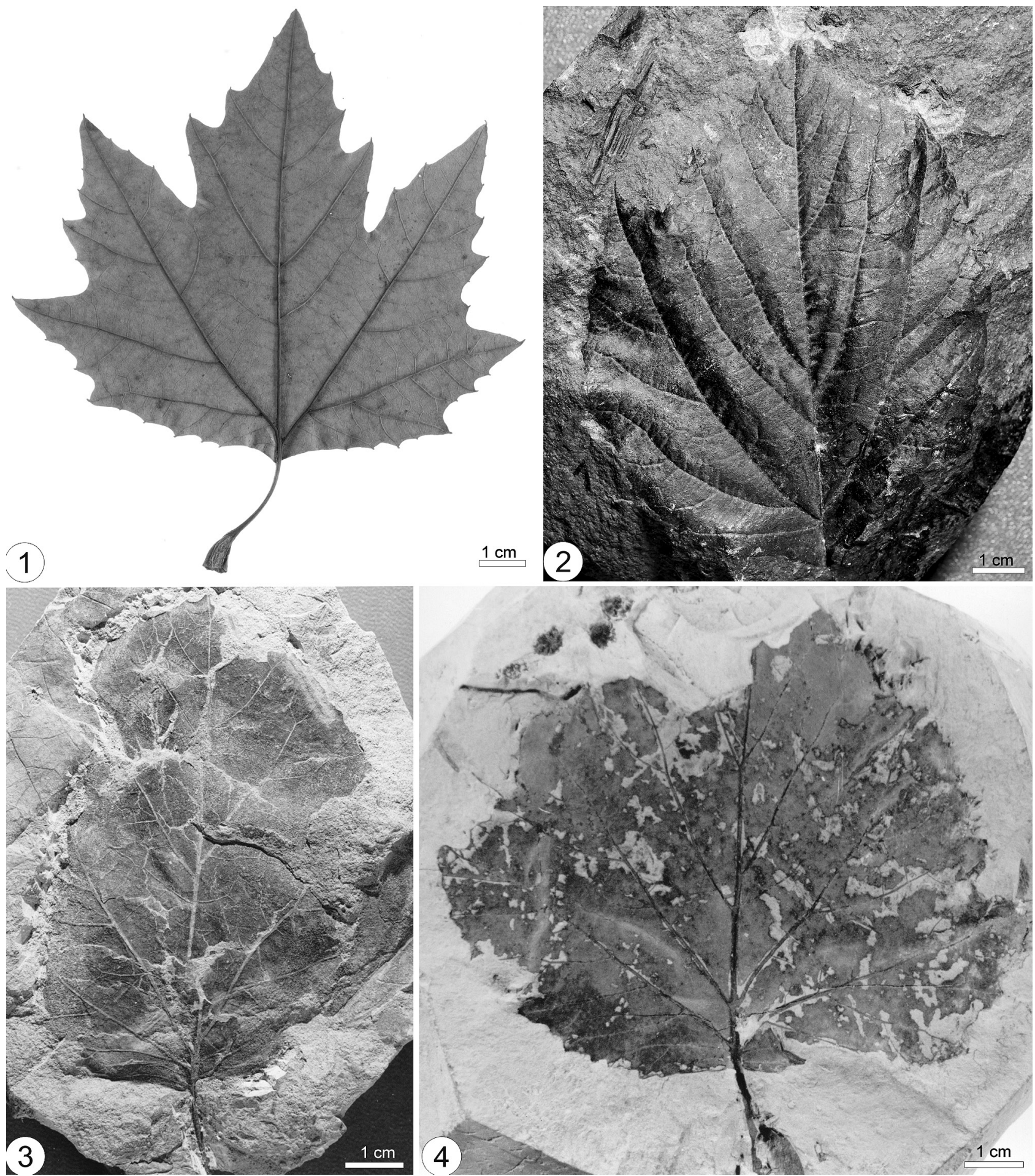

Plate 1 Leaves of extant Platanus occidentalis L. (1) and extinct Platanus-like leaves (2 - 4): 1 - typical lobate leaf; 2 - Ettingshausenia raynoldsii (Newberry) Moiseeva, specimen no. 4843/1a, Amaam Lagoon area, Chukotka, Upper Maastrichtian (Moiseeeva 2012, Pl. 10, fig. 6)); 3 - Ettingshausenia louravetlanica (Herman et Shczepetov) Moiseeva, specimen no. 4875/2-1, Grebenka River (Anadyr' River basin), northeastern Russia, Upper Albian Lower Cenomanian (Maslova \& Herman 2004, Pl. 8, fig. 1); 4 - Platanus-like leaf associated with Kasicarpa melikianii N. Maslova, Golovneva et Tekleva, specimen no. 29/8a, Kas river, Chulym-Yenisey depression, Turonian (Maslova et al. 2005, Fig. 2)

propriate justification, fossil leaves with untypical features. Encyclocytic stoma consists of a single closed ring of 5 or more very small subsidiary cells enclosing the guard cells (Pl. 2, fig. 5). In her publication, Golovneva, however, does not show a single valid photograph of an encyclocytic stoma. The only photograph where this stomata type is claimed to be shown (Golovneva \& Nosova 2012, Pl. 89, fig. 3), is incorrectly interpreted. Indeed what is shown in this photograph is an anomocytic stoma with well-developed peristomatal rim - protrusion of the guard cell wall encircling a stoma. Peristomatal rims may be of different widths and have wrinkles; these wrinkles were possible interpreted by Golovneva as a ring of small subsidiary cells. The development of such a ring is often accompanied by certain xeromorphic morphological features. This is quite common and is not of any taxonomic value. 


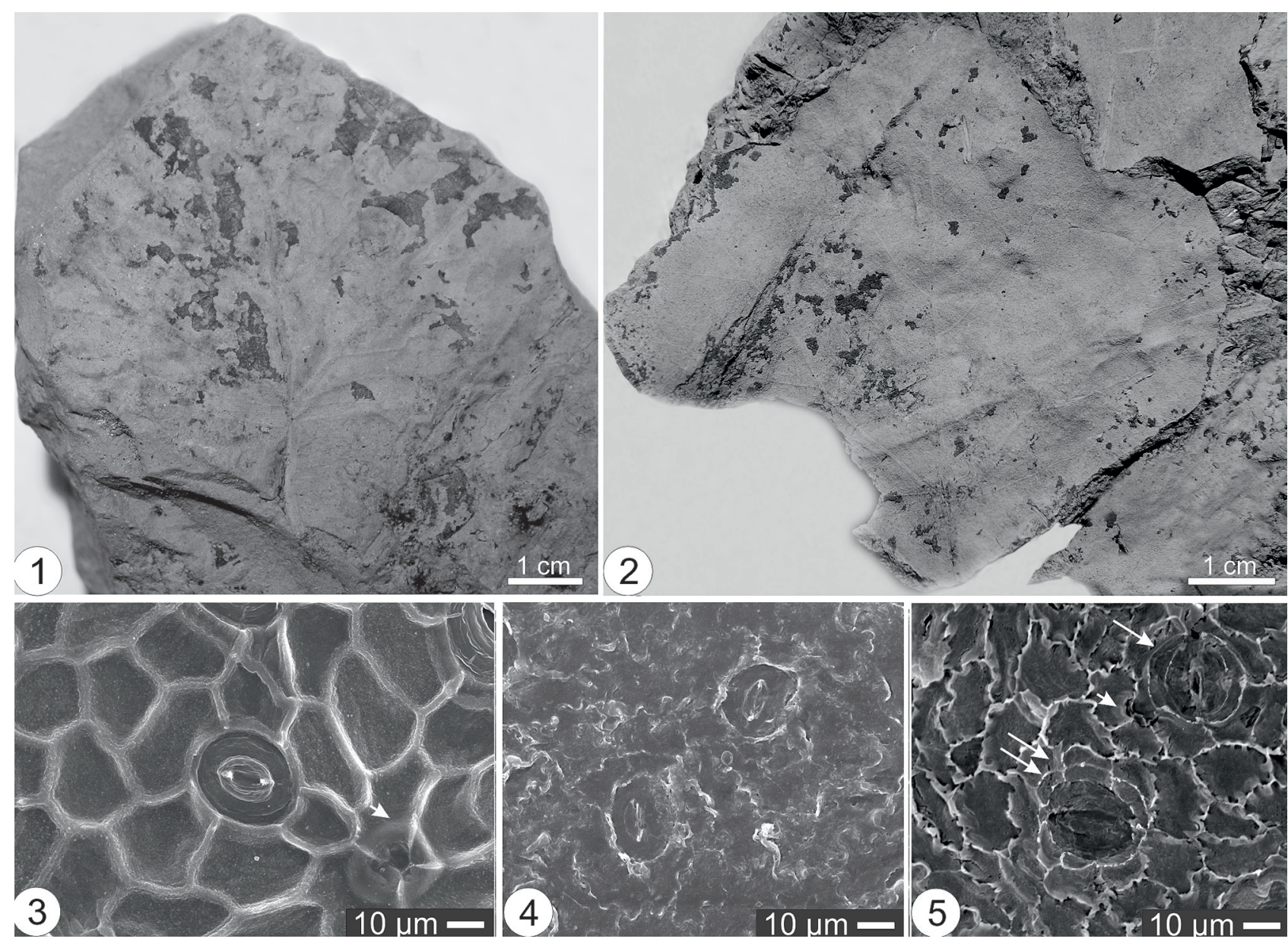

Plate 2 Ettingshausenia leaves $(1,2)$ and cuticle $(4,5)$ and cuticle of extant Platanus (3): 1 - Ettingshausenia kubaensis N. Maslova et Sokolova, holotype no. 5167/10, Kiya river, western Siberia, Albin - Cenomanian (Maslova et al., 2011, Pl. 10, fig. 6); 2 - Ettingshausenia sarbaensis N. Maslova et Shilin, holotype no. 417/33, Sarbay locality, western Kazakhstan, Cenomanian - Turonian (Maslova \& Shilin 2011, Fig. 1, a); 3 - cuticle of Platanus occidentalis L., lower leaf surface, external view, anomocytic stoma and trichome base (shot arrow) are seen; 4 - cuticle of Ettingshausenia kubaensis N. Maslova et Sokolova, lower leaf surface, external view, anomocytic stomata; 5 - cuticle of Ettingshausenia sarbaensis N. Maslova et Shilin, lower leaf surface, internal view, paracytic (arrow), encyclocytic (two arrows) stomata, and trichome base (shot arrow) are visible

It should also be noted that those opposing the use of the generic name Ettingshausenia of Krassilov's morphological classification for dispersed fossil angiosperm leaves erroneously believe that we have suggested the absence of the modern genus Platanus in the Cretaceous. In fact, we have never drawn such a conclusion. In our paper (Maslova et al. 2005b), however, it is shown that at present we simply do not have any reliable evidence of such an early appearance of the modern genus in the fossil record (see also Maslova 2010). Obviously this does not mean that this evidence will not appear in the future. Moreover, Krassilov's morphological classification was proposed not only for the Cretaceous fossils, but also for Cenozoic leaves which systematic position cannot be reliably justified.

Thus, at present the basic principle of the morphological classification, according to which fossil angiosperm leaves of a certain morphotype are merged into a single genus, seems to be correct and therefore should be used for the Cretaceous platanoid leaves identifications. This is also true for different dispersed fossil leaves, particularly those of them, which are morphologically similar to the modern ones. For example, the dispersed Cretaceous leaves similar to those of the modern oak Quercus L. are placed to the genus Barykovia Moiseeva from the group Fagofolia of Kras- silov's morphological classification; at the same time these fossil leaves have features in common with foliage of plants from the family Ulmaceae (Moiseeva 2012).

Recent studies (primarily those of the reproductive structures of Cretaceous angiosperms) have shown that Cretaceous angiosperms differed significantly in most cases from modern plants, and actually reflect the early evolution of this group. It is clear that for the Cretaceous angiospermous leaves we need to use a morphological classification of leaves that is independent from the system of modern plants. The inclusion of dispersed fossil leaves of a particular morphotype in one genus, as an alternative for traditional assignment of fossil angiosperm leaves to taxa of modern plants on the basis of superficial resemblance, seems to be the most effective key for the identification of Cretaceous angiosperm leaves.

Elaboration of classification systems is a key problem of the systematic botany (including palaeobotany). There are different approaches to this problem which are being developed over a long history of scientific progress. Krassilov's morphological classification of the dispersed angiosperm leaves, suggested back in 1979, is still waiting for its further elaboration and certainly deserves a more close attention of the research community. 


\section{ACKNOWLEDGEMENTS}

This paper is written as a part of the research on the state programm No 01201459177 of the Geological Institute, Russian Academy of Sciences (AH).

\section{LITERATURE CITED}

Friis, E.M., P.R. Crane \& K.R. Pedersen 1988. Reproductive structures of Cretaceous Platanaceae. Det Kongelige Danske Videnskaberne Selskab Biol. Skrifter 31:1-55.

Golovneva, L.B. 2011. Genus Ettingshausenia (Platanaceae) in the Cenomanian-Turonian floras of Eurasia. In: Paleobotanica. Vol. 2 (L.B. Golovneva et al., eds.), pp. 127-163. Marathon, Saint-Petersburg (in Russian). ГГоловнева А.Б. 2011. Род Ettingshausenia (Platanaceae) в сеномантуронских флорах Евразии // Палеоботаника, т. 2 / пол реА. А.Б. Головневой и Ар. Санкт-Петербург: Марафон. С. 127-163].

Golovneva, L.B. \& N.B. Nosova 2012. Albian-Cenomanian flora of Western Siberia. Marathon, Saint-Petersburg, 436 pp. (in Russian). ГГоловнева А.Б., Носова Н.В. 2012. А^ьб-сеноманская фмора Западной Сибири. СанктПетербург: Марафон. 436 с.].

Herman, A.B. \& J. Kvaček 2010. Late Cretaceous Grünbach Flora of Austria. Verlag des Naturhistorisches Museum in Wien, Wien, 224 pp.

Krassilov, V.A. 1973. Upper Cretaceous staminate heads with pollen grains. Palaeontology 16: 41-44.

Krassilov, V.A. 1976. The Tsagayan Flora of the Amur Region. Nauka, Moscow, 92 рр. (in Russian). [Красилов B.A. 1976. Цагаянская фмора Амурской области. Москва: Наука. 92 с.].

Krassilov, V.A. 1979. Cretaceous flora of Sakhalin. Nauka, Moscow, 568 pp. (in Russian). [Красилов B.A. 1979. Меловая флора Сахалина. Москва: Наука. 568 с.].

Krassilov, V.A. 1989. The Origin and Early Evolution of Flowering Plants. Nauka, Moscow, 263 pp. (in Russian). [Kpaсилов В.А. 1989. ПроисхожАение и ранняя эволюция цветковых растений. Москва: Наука. 263 с.].

Krassilov, V.A. \& P.V. Shilin 1995. New platanoid staminate heads from the Mid - Cretaceous of Kazakhstan. Review of Palaeobotany and Palynology 85:207-211.

Kvaček, J. \& Z. Váchová 2006. Revision of platanoid foliage from the Cretaceous of the Czech Republic. Journal of the National Museum (Prague), Natural History Series 175(3-4): 77-89.

Manchester, S.R. 1986. Vegetation and reproductive morphology of an extinct plane tree (Platanaceae) from the Eocene of Western North America. Botanical Gazette 147: 200-226

Maslova, N.P. 2003. Extinct and extant Platanaceae and Hamamelidaceae: morphology, systematics, and phylogeny. Paleontological Journal Suppl. 5:467-589.

Maslova, N.P. 2010. Systematics of fossil platanoids and hamamelids. Paleontological Journal 44(11):1379-1466.

Maslova, N.P., L.B. Golovneva \& M.V. Tekleva 2005a. Infructescences of Kasicarpa gen. nov. (Hamamelidales) from the Late Cretaceous (Turonian) of the ChulymEnisey depression, western Siberia, Russia. Acta Paleobotanica 45(2):121-137.

Maslova, N.P., M.G. Moiseeva, A.B. Herman \& J. Kvaček 2005b. Did plane trees exist in the Cretaceous? Paleontological Journal 39(4):440-453.

Maslova, N.P. \& A.B. Herman 2004. New finds of fossil hamamelids and data on the phylogenetic relationships between the Platanaceae and Hamamelidaceae. Paleontological Journal 38(5):563-575]

Maslova, N.P. \& A.B. Herman 2006. Infructescences of Friisicarpus nom. nov. (Platanaceae) and associated foliage of the platanoid type from the Cenomanian of Western Siberia. Paleontological Journal 40(1):109-113.

Maslova, N.P. \& P.V. Shilin 2011. The new species Ettingshausenia sarbaensis (Angiospermae) from the CenomanianTuronian of Western Kazakhstan in light of the problem of classification of dispersed Cretaceous Platanus-like leaves. Paleontological Journal 45(4):459-473.

Maslova, N.P., M.V. Tekleva, A.B. Sokolova, A.V. Broushkin \& N.V. Gordenko 2011. Infructescences of Frïsicarpus kubaensis sp. nov. and leaves of Ettingshausenia kubaensis sp. nov. from the Albian-Cenomanian of Chulym-Yenisei depression, Russia. Palaeobotanist 60(2):209-236.

Meyen, S.V. 1987. Fundamentals of palaeobotany. Chapman \& Hall, New York. 432 pp.

Moiseeva, M.G. 2008. New angiosperms from the Maastrichtian of the Amaam Lagoon area (Northeastern Russia). Paleontological Journal 42(3):313 - 327

Moiseeva, M.G. 2009. The Koryak phase of the flora development in the Northern Pacific Frame. Paleontological Journal 43(6): 702-710.

Moiseeva, M.G. 2012. Barykovia, a new genus of angiosperms from the Campanian of northeastern Russia. Review of Palaeobotany and Palynology 178:1-12.

Narita, A., T. Yamada \& M. Matsumoto 2008. Platanoid leaves from Cenomanian to Turonian Mikasa Formation, northern Japan and their mode of occurrence. Paleontological Research 12(10):81-88.

Shilin, P.V. 2008. Upper Cretaceous flora of Karakumzholy, northeastern Aral Region. Paleontological Journal Suppl. 42(12):1405-1409.

Tschan, G.F., T. Denk \& M. Von Balthazar 2008. Credneria and Platanus (Platanaceae) from the Late Cretaceous (Santonian) of Quedlinburg, Germany. Review of Palaeobotany and Palynology 52:211-236.

Upchurch, G.R. 1984. Cuticle evolution in Early Cretaceous Angiosperms from the Potomac Group of Virginia and Maryland. Annals of the Missouri Botanical Garden 71:522-550.

Vakhrameev, V.A. 1952. Stratigraphy and fossil flora of the Cretaceous of Western Kazakhstan. In: Regional'naya Stratigrafiya SSSR. Vol. 1. (V.A. Vakhrameev \& N.A. Shtreis, eds.), 340 pp. Izdatel'stvo Akademii nauk SSSR, Moscow (in Russian). [Вахрамеев В.А. 1952. Стратиграфия и ископаемая флора меловых отложений Западного Казахстана // Региональная стратиграфия СССР. Т. 1. / под ред. В.А. Вахрамеева и Н.А. Штрейса. Москва: Изаательство АН СССР. 340 с.]

Yarmolenko, A.V. 1935. Upper Cretaceous flora of the Northwestern Kara-Tau. Trudy Sredneaziatskogo Gosudarstvennogo Universiteta, seriya VIII-B. Botanika 28:3-36 (in Russian). [Ярмоленко А.В. 1935. Верхнемеловая флора северо-восточного Кара-Тау // Труды Среднеазиатского государственного университета, серия VIII-Б -Ботаника. Вып. 28. С. 3-36.] 